\title{
ЯЗЫКОВАЯ ИГРА И ЕЕ АНАЛИЗ ПРИ ОБУЧЕНИИ РУССКОМУ ЯЗЫКУ
}

\author{
Дорохин Дмитрий Викторович \\ студент \\ Научный руководитель: Савелова Любовь Анатольевна \\ д. филол. н., доцент \\ ФГАО ВО «Северный (Арктический) \\ федеральный университет имени М.В. Ломоносова»
}

Аннотация: в статье рассматриваются подходы к понятию языковой игры в современном научном дискурсе. Автором раскрываются перспективы использования анализа игровых элементов высказывания при обучении русскому языку в школе. Сделан вывод о преимуществах данного методического приёма.

Ключевые слова: русский язык, методика обучения русскому языку, результаты обучения, языковая игра, высказывание.

\section{LANGUAGE GAME AND ITS ANALYSIS IN TEACHING RUSSIAN}

\section{Dorokhin Dmitry Victorovich Scientific adviser: Savelova Lyubov Anatolyevna}

Abstract: the article discusses approaches to the concept of language game in modern scientific discourse. The author reveals the prospects of using the analysis of the game elements of the utterance when teaching the Russian language at school. The conclusion is made about the advantages of this methodical technique.

Key words: Russian language, methods of teaching the Russian language, learning outcomes, language game, utterance.

Языковая игра в настоящее время расценивается как неотъемлемая характеристика коммуникативного пространства, поскольку она в той или иной степени присуща всем участниками речевого общения. А поскольку, согласно ФГОС, формирование коммуникативных компетенций является одним из результатов освоения программы по русскому языку, то становится важным изучение этого явления в школе. Внимание к игровой стороне высказывания 
способствует формированию компетенций, связанных с осмысленным восприятием и использованием ресурсов языка, что способствует развитию речи и совершенствованию коммуникативных навыков обучающихся.

Дадим представление об основных подходах к понимаю языковой игры.

В концепции В.3. Санникова языковая игра - это некая языковая неправильность, которую автор осознаёт и допускает намеренно. Она также зависит от слушающего или читающего, от его мотивации понимать и поддерживать игру. Он отмечает, что языковая игра основана на знании системы единиц языка, нормы их использования и способов творческой интерпретации этих слов [1, с. 15].

Согласно Т.А. Гридиной языковая игра представляет собой «особую форму лингвокреативной деятельности, отражающей стремление говорящего к обнаружению собственной компетенции в реализации языковых возможностей - при понимании условности совершаемых речевых ходов, но в то же время рассчитанных на «опознание» реципиентом негласно принятых правил общения» [2, с. 26]. То есть автор стремится проверить свои возможности в использовании языка, а слушатель или читатель в опознавании этого и декодировании авторской коммуникативной установки.

Н.В. Данилевская описывает языковую игру как определенный тип речевого поведения говорящих, который строится на сознательном нарушении речевых норм с целью создать какие-то нестандартные языковые формы, способные вызвать эстетический эффект у слушателя [3, с. 657].

По А.П. Сковородникову - языковая игра представляет собой также сознательный уход от нормы и творческое использование языковых средств с целью создания остроумных выражений, которые вызывают чаще всего комический эффект $[4$, с. 2$]$.

Мы считаем, что изучение данного явления и применение анализа игровых элементов высказываний в рамках решения проблем обучения русскому языку в школе даёт сегодня учителю ряд преимуществ в выстраивании образовательного процесса.

Использование этого методического приёма наиболее эффективно в старших классах при изучении таких разделов, как «Лексикология и Фразеология». Однако не исключаем, что его можно использовать, обучая и другим разделам, например, таким как «Речь и речевое общение» или «Культура речи». Важно подчеркнуть, что проведение анализа игровых элементов высказываний требует предварительной подготовки. 
Мы рекомендуем давать его школьникам в дополнение к другим упражнениям. В рамках данной статьи мы бы хотели уделить внимание тому, как осуществляется данный анализ.

Примеры языковой игры были взяты из произведения Ильфа и Петрова «Двенадцать стульев». Мы признаём, что данное произведение может быть неизвестно школьникам, но мы полагаем, что трудностей в работе с примерами возникнуть не должно. Особенно если педагог будет активно их комментировать. В то же время - это хорошая возможность познакомить школьников с классическим произведением русской литературы, которому сегодня в школе не всегда уделяют специальное внимание.

1) - Не меньше. Только вы, дорогой товарищ из Парижа, плюньте на все это.

- Как плюнуть?

- Слюной...

В этом примере используется приём обыгрывания неоднозначности. Авторы используют слово плюньте в прямом и переносном значении в одном контексте. Сначала Остап Бендер говорит плюньте в переносном значении, предлагая Кисе Воробьянинову перестать думать об определённом деле, задаёт ему риторический вопрос «Как плюнуть?» на что Бендер, отвечает «Слюной», употребляя слово плюньте уже в прямом значении. За счёт этого создаётся комический эффект.

2) - А с какой целью взимается плата?

- C целью капитального ремонта Провала, чтоб не слишком проваливался.

В данном диалоге реализуется приём игры с сочетаемостью слов. Здесь можно говорить о сознательно допущенной ошибке авторов - употреблении однокоренных слов, что приводит к каламбурности высказывания. Это делает описываемую ситуацию комичной и абсурдной.

3) - Время, которое у нас есть, - это деньги, которых у нас нет.

Авторы реализуют в этом примере приём игры с прецедентными феноменами. «Время - деньги» цитата Бенджамина Франклина. Ильф и Петров по-своему выворачивают её. Остап Бендер в данном контексте выражает досаду из-за неудач в поисках сокровищ с Кисой. Прием хиазма.

4) - Вот это ваш мальчик?

- Кто скажет, что это девочка, пусть первый бросит в меня камень! 
Тут мы также наблюдаем пример игры с прецедентными феноменами. «Пусть первым бросит в меня камень» - это выражение, взятое из эпизода Нового завета «Христос и грешница». Часто оно цитируется как шутливоироническая форма ответа на необъективную критику, но в данном контексте скорее усиливает уверенность Остапа в его беспроигрышной позиции. Дополнительно к этому в слове мальчик в условиях контекста одни семы актуализируются ('мужской пол'), другие практически стираются ('невзрослый, ребенок'), в результате чего возникает нетривиальная интерпретация вполне обыденного понятия, улавливается речевая хитрость героя (и авторов).

Итак, внедрение такого вида анализа способствует развитию творческого потенциала учеников, он активизирует познавательную деятельность, позволяет расширить кругозор. Мы полагаем, что использование такого анализа в школе в полной мере соответствует концепции системнодеятельностного подхода, который признан ФГОС как основной в работе педагога сегодня. Анализ игровых элементов позволяет сформировать знания о фразеологизмах, лексической и фразеологической сочетаемости слов, способах создания высказывания с комической модальностью. В комплексе всё это способствует решению многоуровневой образовательной задачи, включающей обучающий, воспитательный и развивающий компоненты.

Преимущества использования данного приема на занятиях по русскому языку, в том числе в рамках внеурочной деятельности, заключаются в том, что он позволяет не только выявить и сформировать творческое и осмысленное отношение к высказываниям со стороны обучающихся, но и проявляет педагогическую индивидуальность учителя. Это способствует формированию особой атмосферы творческого поиска, которая, как представляется, играет большую роль в постижении функционально-семантического разнообразия и богатства ресурсов русского языка.

\section{Список литературы}

1. Санников В. 3. Русский язык в зеркале языковой игры. - М.: Языки русской культуры, 1999. - 541 с.

2. Гридина Т. А. Языковая игра как лингвокреативная деятельность // Язык. Система. Личность. Языковая игра как вид лингвокреативной деятельности. Формирование языковой личности в онтогенезе. - Екатеринбург, 2002. - C. 26-27. 


\section{3. Данилевская Н. В. Языковая игра // Стилистический} энциклопедический словарь русского языка / под ред. М. Н. Кожиной. - М.: Флинта: Наука, 2003. - С. 657-660.

4. Игра как прием текстопорождения: коллективная монография / под ред. А. П. Сковородникова. - Красноярск: Сибирский федеральный университет, 2010. -340 c.

() Д. В. Дорохин, 2022 